Gholamreza KARAMIAN* (Polish Institute of Advanced Studies, Poland)

Kaveh FARROKH $^{* *}$ (Methodologica Governance University, Paris, France)

\title{
A unique Parthian sword in the Bonyad-e Mostazafan Museum
}

https://doi.org/10.34739/his.2019.08.15

Abstract: This study is going to introduce one of the unique and less known Parthian sword which have not been released to public for purpose of exhibit and study so far.

Key words: Parthian military, sword, Bonyad-e Mostazafan Museum, Iran

This study is going to introduce one of the unique and less known Parthian sword which have not been released to public for purpose of exhibit and study so far. There is one Parthian sword made of Iron, double edges in the Bonyad-e Mostazafan Museum, Tehran (inv. 44797). The handle of the sword properly was in wood or bone because of badly decay there is no sign of handle however the handle bar is still survived.

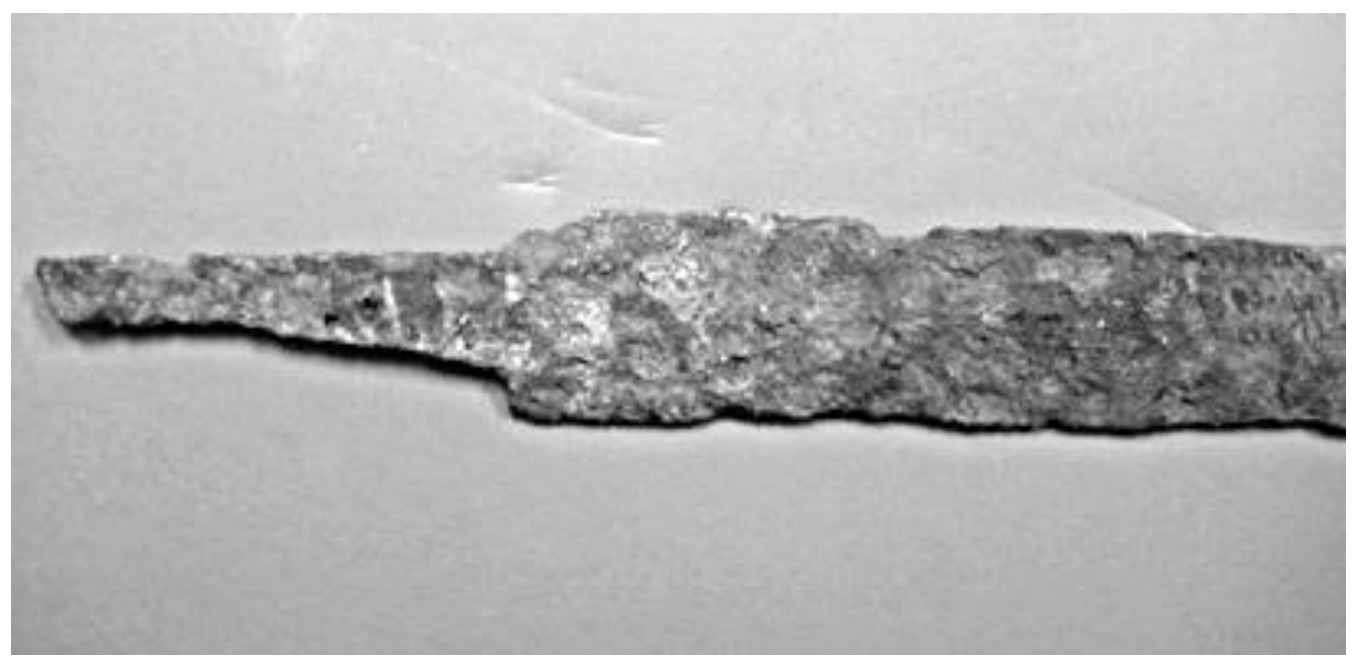

* ORCID iD 0000-0003-4200-2592. karamianreza@yahoo.com; First of all I would like to offer my special appreciation to Ms. Mitra Haji who is as an asset for Bonyad-e Mostazafan Museum.

** ORCID iD 0000-0001-5732-2447. manuvera@aol.com 

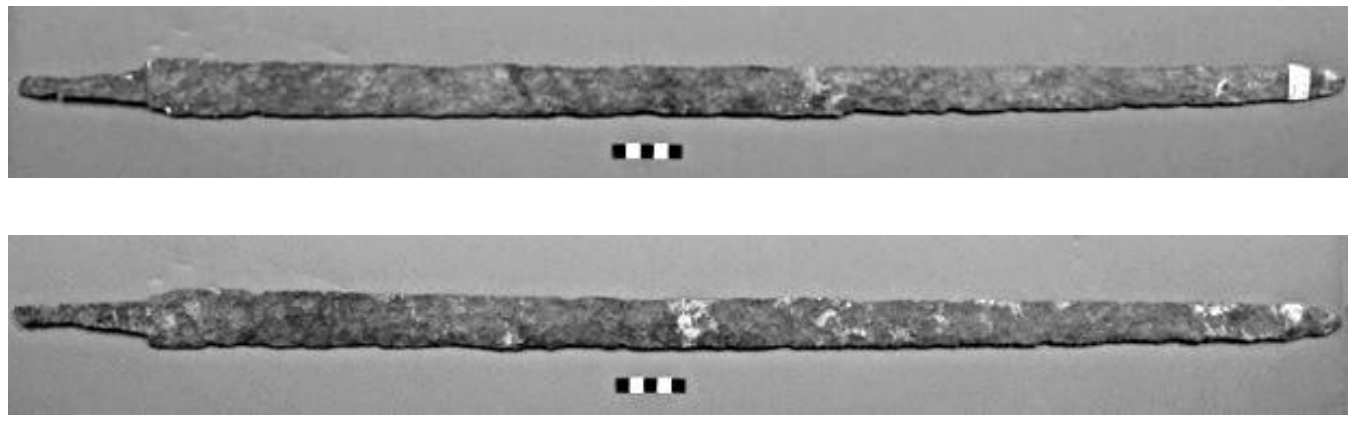

Fig. 1. Parthian sword, the Bonyad-e Museum; Tehran, inv. 44797.

Total measurements are as follows:

Total length: $98 \mathrm{~cm}$

Length of handle: $9.7 \mathrm{~cm}$

Width of the blade close to the handle part: $4.3 \mathrm{~cm}$

Width of the blade in the middle part: $3.6 \mathrm{~cm}$

The closest Parthian swords to the Bonyad-e sample is one of the Parthian swords in Iran Bastan Museum in Tehran. It is long kind of Parthian sword made of Iron with $83 \mathrm{~cm}$ length and blade and handle are so similar to Bonyad-e sword style.

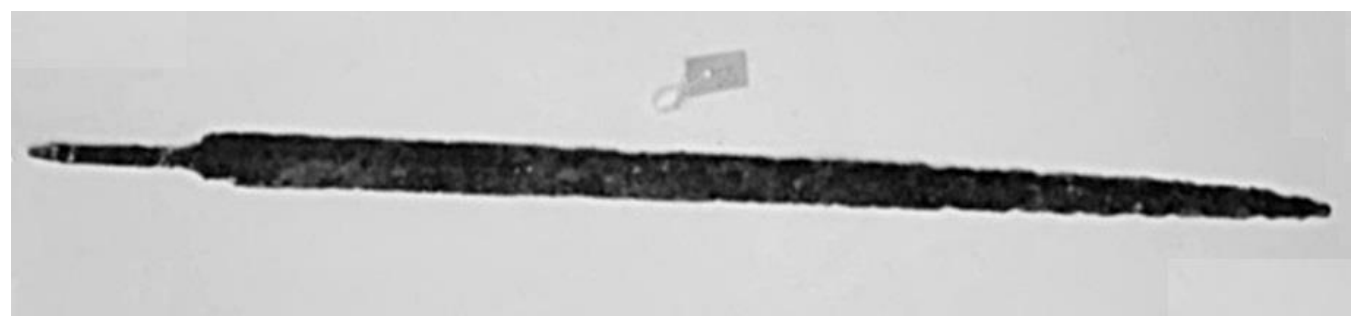

Fig. 2. Parthian sword, Iran Bastan Museum, Tehran; inv. 1604/18029.

There is another Parthian sword in Iran Bastan Museum. It is long category of the Parthian swords with $84 \mathrm{~cm}$. length. It is also iron made like Bonyad-e sword.

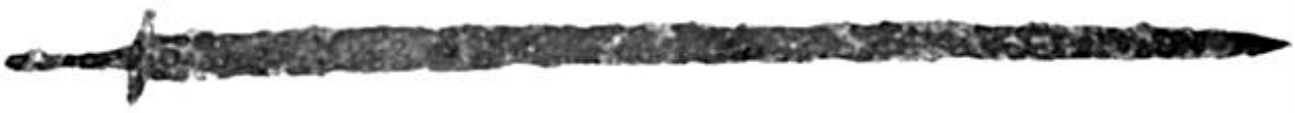

Fig. 3. Parthian sword, Iran Bastan Museum, Tehran; inv. 3630/19198. 
Table 1: Comparison of Parthian long swords housed at Iran Bastan Museum

\begin{tabular}{|c|c|c|c|c|}
\hline & $\begin{array}{c}\text { Inv. No: } \\
1603 / 18028\end{array}$ & $\begin{array}{c}\text { Inv. No: } \\
1604 / 18029\end{array}$ & $\begin{array}{c}\text { Inv. No: } \\
3630 / 19198\end{array}$ & $\begin{array}{c}\text { Inv. No: } \\
3631 / 19199\end{array}$ \\
\hline Characteristics & no designs & $\begin{array}{l}\text { no designs, small nail } \\
\text { at end of sword }\end{array}$ & no designs & no designs \\
\hline $\begin{array}{l}\text { Length (handle } \\
\text { to sword tip) }\end{array}$ & $62 \mathrm{~cm}$ & $83 \mathrm{~cm}$ & $84 \mathrm{~cm}$ & $87.5 \mathrm{~cm}$ \\
\hline Weight & $495 \mathrm{gm}$ & $438 \mathrm{gm}$ & na & na \\
\hline Color & $\begin{array}{l}\text { "Burnt" dark } \\
\text { brown }\end{array}$ & "Burnt" dark brown & na & na \\
\hline Material & Iron & Iron & Iron & Iron \\
\hline Excavation site & $\begin{array}{l}\text { Nowruz } \\
\text { Mahalleh, } \\
\text { Deylaman }\end{array}$ & $\begin{array}{c}\text { Nowruz Mahalleh, } \\
\text { Deylaman }\end{array}$ & Rasht, Gilan & Rasht, Gilan \\
\hline Excavation year & 1960 & 1960 & 1966 & 1966 \\
\hline $\begin{array}{l}\text { Current } \\
\text { condition }\end{array}$ & Rusted & Rusted & $\begin{array}{l}\text { Rusted, part of } \\
\text { blade broken off }\end{array}$ & $\begin{array}{l}\text { Rusted, } \\
\text { slight bend, } \\
\text { broken }\end{array}$ \\
\hline
\end{tabular}

Table 2: Dimensions of excavated swords from gravesites/crypts at Vestemin

\begin{tabular}{|l|c|c|c|c|c|c|}
\cline { 2 - 7 } \multicolumn{1}{c|}{} & $\begin{array}{c}\text { Length } \\
\text { of sword } \\
\text { handle } \\
(\mathrm{cm})\end{array}$ & $\begin{array}{c}\text { Length } \\
\text { of sword } \\
\text { blade } \\
(\mathrm{cm})\end{array}$ & $\begin{array}{c}\text { Width } \\
\text { of blade } \\
(\text { at center }) \\
(\mathrm{cm})\end{array}$ & $\begin{array}{c}\text { Dimensions } \\
\text { of } \\
\text { hand guard } \\
(\mathrm{cm})\end{array}$ & $\begin{array}{c}\text { Blade } \\
\text { thickness } \\
(\mathrm{mm})\end{array}$ & $\begin{array}{c}\text { Total } \\
\text { sword } \\
\text { length } \\
(\mathrm{cm})\end{array}$ \\
\hline Sword 1 & 7.5 & 63 & 3.5 & $10 \times 2 \times 1.3$ & 5.0 & 74.0 \\
\hline Sword 2 & 10.5 & 68 & 3.7 & $10 \times 1.5 \times 1.2$ & 4.0 & 80.0 \\
\hline Sword 3 & 10.0 & 78.5 & 4.0 & $10 \times 2 \times 1.3$ & 5.0 & 90.0 \\
\hline Sword 4 & 6.4 & 67 & 3.3 & $10 \times 1.5 \times 0.6$ & 4.0 & 74.0 \\
\hline Sword 5 & 16 & 76 & 6.0 & na & 5.0 & 92.0 \\
\hline
\end{tabular}




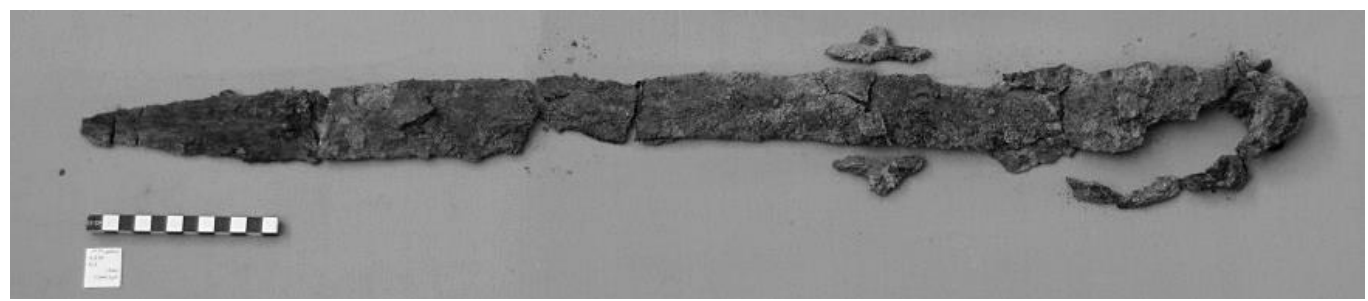

Fig. 4. Parthian sword excavated from a crypt/grave at the eastern side of the Vestemin site - for dimensions see "Sword 5" in Table 2.

Five swords have been discovered at Vestemin. The swords range from a maximum length of $92 \mathrm{~cm}$ to the shortest at $74 \mathrm{~cm}$. One of the unique characterisric of the Bonyad-e sword as campare to the other parthians swords samples is, its measurments. The Bonyad-e parthian sword is the longest amoung all parthian swords which have ever been found. The following table shows the measurments of recent parthian found in Vestmin which have been studied by athours no swords in these site is as lomg as Bonyad-e sample.

\section{Bibliography}

FARROKH K., KARAMIAN G., DELFAN M., ASTARAKI F. (2016), 'Preliminary reports of the late Parthian or early Sassanian relief at Panj-e Ali, the Parthian relief at Andika and examinations of late Parthian swords and daggers'. Historia i Świat 5, 31-55.

KARAMIAN G., FARROKH K., KIAPI M.F., LOJANDI H.N. (2018), 'Graves, Crypts and Parthian Weapons excavated from the Gravesites of Vestemin', Historia $i$ Świat 7, 35-70.

WINKELMANN S. (2013), 'The weapons of Hatra as reflection of interregional contacts', in Hatra: Politics, Culture, Religion between Parthia and Rome, L. DIRVEN (ed.) Stuttgart, 235-361. 